\title{
Managerial Coaching Behaviours and Their Relations to Job Satisfaction, Life Satisfaction and Orientations to Happiness
}

\author{
Guohai Chen, Jie Ai, Yamin You \\ School of Management, Guangdong University of Foreign Studies, Guangzhou, China \\ Email: mypeer2002@hotmail.com
}

Received 24 June 2014; revised 27 July 2014; accepted 12 August 2014

Copyright @ 2014 by authors and Scientific Research Publishing Inc.

This work is licensed under the Creative Commons Attribution International License (CC BY). http://creativecommons.org/licenses/by/4.0/

\section{(c) (i) Open Access}

\section{Abstract}

This paper aims to explore managerial coaching behaviours and their relations to job satisfaction, life satisfaction and orientations to happiness. Chinese Managerial Coaching Behaviours Inventory, Chinese translation of the Orientations to Happiness Scale, General Job Satisfaction Scale and General Life Satisfaction Scale were administered to 145 managers from two factories, one hospital, China Mobile and China Telecom. Results indicate that: Unexpectedly, managerial coaching behaviours are not associated with job satisfaction and life satisfaction. Pleasure of life in Orientations to Happinessis significantly associated with assessing and challenging dimensions of Managerial Coaching Behaviours Inventory. Both job satisfaction and life satisfaction are significantly positively related with all the three dimensions in Orientations to Happiness. Females show more supporting behaviours than males. Compared with the first-line managers and technicians with titles, the middle and senior managers show more challenging and supporting behaviours. Compared with the factory managers, managers in hospitals, China Mobile and China Telecom show more challenging and supporting behaviours. Pleasure of life was positively related to assessing and challenging behaviours.

\section{Keywords}

Managerial Coaching Behaviours, Job Satisfaction, Life Satisfaction, Orientations to Happiness, Relations, China

\section{Introduction}

Coaching has been recognized as an essential success factor in fostering innovation and managerial flexibility

How to cite this paper: Chen, G.H., Ai, J. and You, Y.M. (2014) Managerial Coaching Behaviours and Their Relations to Job Satisfaction, Life Satisfaction and Orientations to Happiness. Journal of Human Resource and Sustainability Studies, 2, $147-156$. 
(Jones et al., 2006) [1]. According to Ennis et al. (2004) [2] coaching is provided by the organization and involves a clear link between the individual goals of the coachee and the strategic goals of the organization. Richard (1994) [3] defined coaching as a skill concerned with creating conditions for people to perform their abilities best. He pointed out that coaching managers' key means in promoting organizational performance is to help staff to learn, grow and develop.

Literature indicates that coaching is critical to the success of managers themselves and their employees (Goodstone \& Diamante, 1998; Hudson, 1999; Longenecker, 2010) [4]-[6]. Therefore, managerial coaching will be the focus of this paper. Managerial coaching is defined as "a manager acting as a coach to help his or her staff learn and develop” (Ellinger \& Bostrom, 1999; Beattie, 2002; Talarico, 2002) [7]-[9].

Although researches on coaching or managerial coaching in particular are growing, literature on coaching is overly theoretical and prescriptive. There are few empirical studies on coaching behaviours and little empirical evidence on the effects of coaching (Graham et al., 1993, 1994; Beattie, 2002; Janka, 2008) [8] [10]-[12]. In recent years, scholars have begun to conduct empirical studies to examine managerial coaching behaviours. Empirical researches on managerial coaching have examined effective and ineffective managerial coaching behaviours and skills (Ellinger \& Bostrom, 1999; Beattie, 2002; Andrea, 2008; Clinton, 2010) [7] [13] [14] and the application of managerial coaching in specific context or organization (Andrea et al., 1999; Alexander et al., 2005) [14] [15].

Andrea (2008) [14] conducted a cross-national study on behavioural indicators of ineffective managerial coaching. She analyzed 17 ineffective behaviours and figured out predominant ineffective behaviours. More attention has been given to empirical studies on effective managerial coaching behaviours. Ellinger and Bostrom (1999) [7] classified 13 managerial coaching behaviours into 2 categories, namely, facilitating and empowering. Beattie's (2002) [7] research on effective managerial coaching in the context of a social service organization explored 22 irrelevant effective facilitative behaviours that falls into 9 behavioural categories: thinking, informing, empowering, assessing, advising, being professional, caring, developing others and challenging employees to stretch themselves.

Alexander et al. (2005) [15] examined the association between warehouse worker development and managerial coaching in the logistics industry. They indicated that there was a significant positive association between supervisory coaching behaviour, warehouse workers' job satisfaction and supervisors' perceptions of their subordinates' job-related performance although warehouse workers are at low levels of supervisory coaching behaviour.

Noer (2005, 2007) [16] [17] established a triangle coaching model with equally important dimensions, namely, assessing, challenging, and supporting. The triangle model borrowed ideas from client-centered research stream of the Center for Creative Leadership (McCauley et al., 1998) [18] and the three dimensional interventionist theory (Argyris, 1973) [19]. He also established behavioural components which are congruent with core criteria for each dimension. Supporting dimension indicates "the creation of an interpersonal context which can facilitate trust, openness, respect and understanding”. It involves four components: attending, inquiring, reflecting and affirming, respectively. Challenging dimension means "stimulating the person being coached to confront obstacles, reconceptualize issues, and move forward with renewed energy and self-reliance". The four behavioural components are confronting, focusing/shaping, reframing and empowering/energizing. Assessing dimension involves "analytical processes that lead to measurement and goal setting". The four behavioural components are data gathering, gap analysis, goal setting and measurement/feedback.

The Coaching Behaviours Inventory was developed on the basis of the triangle coaching model (Noer, 2005) [16]. In the scope of Coaching Behaviours Inventory, thirty items are selected from more than fifty alternative ones, ten for each dimension. Pilot studies were made and the model was applied to compare managerial coaching behaviours between Saudi Arabian and American managers (Noer, 2005, 2007) [16] [17]. Programs and researches carried out in the past have indicated the high internal consistency of dimensional scales within and between cultural sub-groups. Chen, Huang \& Tang developed Chinese Managerial Coaching Behaviour Inventory with 46 items, including three subscales (Assessing, Challenging and Supporting). They also proved the high internal consistency of each subscale of the Inventory. Therefore, it is reasonable to apply this scale into the research into managerial coaching behaviours and their relations to job satisfaction, life satisfaction, and orientations to happiness in the Chinese context.

Job satisfaction has been a heated discussed topic among managers. Vroom (1964) [7] regarded it as "the positive orientation of an individual towards the work role which he is presently occupying”. In recent decades, do- 
zens of studies have been conducted on relationships between job satisfaction and different variables. Debates on causal relationships of satisfaction and performance lasted for a long time (Brayfield \& Crockett, 1955; Vroom, 1964; Lawler \& Porter, 1967; Schwab \& Cummings, 1970; Organ, 1977) [20]-[24], but no agreement had been reached on this issue by mid-1980s (Petty et al., 1984) [25]. Petty et al. (1984) [25] indicated that strength of relationships between performance and satisfaction varied at different job levels with stronger relationships among higher levels employees. Crossman and Nestle (2003) [26] conducted a study on relationships between job satisfaction and job performance in Lebanese commercial banking sector. The results showed no significant relationship between the two variables. Studies have also been conducted on relationships between job satisfaction and demographic factors such as age (Gibson \& Kelein, 1970; Lee \& Wilbur, 1985; Kong et al., 1993; Clark et al., 1996) [27]-[30] and gender (Murray \& Atkinson, 1981; Witt \& Nye, 1992; Chui, 1998; Crossman \& Nestle, 2003) [26] [31]-[33]. Lots of studies of psychological and genetic influences on job satisfaction can also be found (Staw \& Ross, 1985; Arvey et al., 1989; House et al., 1996; Abraham, 1998; Pelled \& Xin, 1999) [34]-[38].

Although the causal relationships of various variables and job satisfaction are controversial, previous studies have provided a great number of factors which are believed to have association with job satisfaction. In addition to the factors mentioned above, Droussiotis (2007) [39] indicated that self-fulfillment, independence, and job environment influence managers' job satisfaction. According to his study, high job satisfaction attributes to factors such as good pay and benefits, highly-skilled subordinates, opportunities for personal growth and advancement in the company, company policies that allow for self-fulfillment and independence, and good work environment. Verhofstadt et al. (2007) [40] revealed the association between education background and job satisfaction. They pointed out that higher educated people enjoyed higher job satisfaction than those with lower education if jobs met their expectations. But the level of job satisfaction drops if their jobs can not meet their expectations. McCausland et al. (2005) [41] found that performance-related pay had a positive effect on the mean job satisfaction of high-paid workers but negative for low-paid ones. Goris (2007) [11] found that communication satisfaction was a predictor of job satisfaction. The influence of communication satisfaction on job satisfaction is significant. Kavanaugh et al. (2006) [42] suggested that professional experience was the major demographic variable which was significantly associated with healthcare professionals' job satisfaction. Oshagbemi (2003) [43] found that the rank of an individual was positively and strongly correlated with the overall job satisfaction while the length of service is negatively related among UK's university teachers. Previous studies also indicated the association between life satisfaction and job satisfaction. Hart (1999) [44] once pointed out that job satisfaction contributed to overall life satisfaction.

Life satisfaction is a concept which is equivalent in meaning with subjective well-being (Judge, 1998) [45]. Subjective well-being is an area with three hallmarks (Diener, 2009) [46]. First, it is an indispensable part of individual's experience (Campbell, 1976) [47]. Second, it includes positive measures of mental health. Third, subjective well-being measures include an integrated assessment of a person's life (Diener, 2009) [46].

Several subjective well-being measures have been developed in western context in recent decades. Satisfaction with Life Scale (SWLS) was developed by Diener et al. (1985) [48]. Watson et al. (1988) [49] proposed the Positive and Negative Affect Schedule (PANAS). In recent years, Temporal Satisfaction with Life Scale (Pavot et al., 1998) [50], Oxford Happiness Inventory (Argyle et al. 1995; Hills \& Argyle 1998) [51] [52], and the Orientations to Happiness Scale (Peterson et al., 2005) [53] have been developed in order to explain how and why people experience their lives in positive ways, including both cognitive judgments and affective reactions (Diener, 2009) [46].

Happiness is one of the subjective well-being measures (Veenhoven, 1994) [54]. Various perspectives on well-being have aroused interest in studying different paths to happiness. Among all these studies, Orientations to Happiness Scale developed by Peterson and his collaborators is widely known. They identified three ways to be happy, namely, pleasure, engagement, and meaning. They examined the association between three orientations to happiness and life satisfaction with a sample of 845 participants. They found that the three orientations to happiness individually predicted life satisfaction. Eighteen items were applied in the assessment. Peterson et al. (2005) [53] concluded that participants who had high score on pleasure, engagement and meaning enjoy high life satisfaction.

With the publication of Orientations to Happiness Scale developed by Peterson et al., several studies have been conducted on the basis of the scale afterwards. Chen (2010) [55] examined the reliability and validity of the Orientation to Happiness Scale with a sample of 671 Chinese correspondents. The results generally sup- 
ported the validity and usefulness of the Orientation to Happiness Scale. Cross-cultural research was also made with the application of the scale (Ruch et al., 2007) [56]. Park et al. (2009) [46] investigated adults from 27 different nations to examine the relationship between orientations to happiness and life satisfaction. The results are quite similar with those of Peterson et al. (2009) [57]. The association between engagement and meaning with life satisfaction is higher than the association between pleasure and life satisfaction. The study also validates that three orientations to happiness can predict life satisfaction.

Although research on job satisfaction and its relation to orientations to happiness is difficult to find, it is still reasonable to predict that the two variables have association on the basis of the research findings on the association between orientations to happiness and life satisfaction.

The aim of the present research is to find out managerial coaching behaviours and their relations to job satisfaction, life satisfaction and orientations to happiness. Relations between job satisfaction and orientations to happiness will also be studied. Moreover, according to Watkins and Leign (2010) [58], coaching has been associated with producing long-lasting learning, contributing to higher levels of motivation, improving employee performance, enhancing working relationship, job satisfaction and organizational commitment. Literature also indicates that variables, for instance, gender differences (Millard, 1996) [59], psychosocial behaviour (Smith et al., 1979; Black \& Weiss, 1992) [60] [61], the numbers of people coached (Sussman \& Finnegan, 1998) [62] are related with coaching. Moreover, Ellinger and Keller's (2003) [63] study revealed that supervisory coaching behaviour is positively associated with employees' job satisfaction and performance. According to previous research findings, it is reasonable to find out that, to some degree, variables that are related with coaching overlap with those which are related with job satisfaction. As stated before, job satisfaction is one of the variables which regarded to have association with coaching and it is also associated with orientations to happiness. Therefore, the research on managerial coaching behaviours and their relations to job satisfaction and orientations to happiness is feasible. It is hypothesized here that job satisfaction, life satisfaction and orientations to happiness can predict managerial coaching behaviours or vice versa.

Four hypotheses are raised in this paper as follows:

H1: Managerial coaching behaviours (assessing, supporting, and challenging) is positively correlated with job satisfaction.

H2: Managerial coaching behaviours (assessing, supporting, and challenging) is positively correlated with life satisfaction.

H3: Managerial coaching behaviours (assessing, supporting, and challenging) is positively correlated with orientations to happiness (pleasure, meaning and engagement).

H4: Job satisfaction is positively correlated with orientations to happiness (pleasure, meaning and engagement).

\section{Method}

\subsection{Participants and Procedure}

Research participants are 145 managers including 78 males and 67 females from three sectors in Pearl River Delta in P. R. China. Among the participants, 55 are managers from a hospital; 56 are managers from one shoe factory and one printing factory; and 34 are managers from China Mobile and China Telecom. In terms of their titles, 62 are line managers; 45 are middle and senior managers; and 38 are technicians with titles. The mean age of the participants is 33.1 years old $(S D=7.6)$.

In the hospital and factories, questionnaires were respectively handed out by the units directly to managers to fulfill within one week. In China Mobile and China Telecom, questionnaires were sent to managers by emails with the help of the human resource department of China Mobile and China Telecom. Questionnaires were fulfilled within two weeks. Finally, 150 of 170 questionnaires were got back with response rate of $88.2 \%$. Among them, 145 questionnaires are valid.

\subsection{Measures}

\section{- Demographic Description}

Personal information, including gender, age, and level of job position, was collected to analyze their relations with managerial coaching behaviours. 


\section{- Chinese Managerial Coaching Behaviour Inventory}

It was used to measure the coaching behaviours of managers in enterprises or technicians with apprentices. The scale consists of 46 items ((Chen, Huang \& Tang, 2013) [64]. There are three sub-scales (assessing, challenging and supporting) within the Chinese Managerial Coaching Behaviours Inventory. Assessing scale consists of 11 items. A sample item is "I often collect comments on my subordinates from other staff." Challenging scale consists of 15 items. A sample item is "I often discuss with my subordinates about his or her misgivings and misconcepts in order to help him or her break through his or her self-handicapping.” Supporting scale consists of 20 items. A sample item is "I talk with my subordinates with open body language, gentle and soft tone and natural eye contact.” Chinese Managerial Coaching Behaviours Inventory is designed by adopting 5-point Likert scale ranging from 1 to 5 which, in sequence, indicate "I almost never adopt this behaviour", "I seldom adopt this behaviour”, "I adopt this behaviour sometimes”, "I often adopt this behaviour”, "I always adopt this behaviour”. In this study, Cronbach’s alphas for subscales, namely, Assessing, Challenging and Supporting are respectively $0.87,0.91$ and $0.92(\mathrm{~N}=196)$ which are high.

- Chinese Translation of Orientations to Happiness Scale

The validity of Chinese Translation of the Orientations to Happiness Scale in Chinese context was proved by Chen (2010) [55]. There are 17 items in the Chinese Translation of Orientations to Happiness Scale with 6 in "pleasure" subscale and "meaning" subscale and 5 in "engagement" subscale. The Chinese Translation of Orientations to Happiness Scale is applied into the present study. 17 items fall into three dimensions, namely, Pleasure, Meaning and Engagement. The scale adopts 5-point Likert scale ranging from 1 to 5 with " $5=$ very much like me”, “4 = basically like me”, “3 = somewhat like me”, “2 = only a little like me” and " $1=$ completely unlike me”. Cronbach’s alphas for three dimensions, namely, Pleasure, Meaning and Engagement are 0.74, 0.77 and $0.66(\mathrm{~N}=671$; Chen, 2010) [55].

- General Job Satisfaction Scale

General Job Satisfaction Scale is a one-item scale with purpose of testing the degree of participants' job satisfaction in general. It adopts 5-point Likert scale ranging from " 1 = very unsatisfied” to " 5 = very satisfied".

- General Life Satisfaction Scale

General Life Satisfaction Scale is a one-item scale. It is applied to measure general life satisfaction. Participants are asked to rate their satisfaction of their lives in general. It adopts 5 -point Likert scale ranging from " $1=$ very unsatisfied" to " 5 = very satisfied". The usefulness of one-item General Life Satisfaction Scale is supported in previous studies (e.g., Chen, 2010) [55].

\subsection{Data Analysis}

Firstly, the single factor analysis of variance (One-way ANOVA) was used to analyze descriptive characteristics, namely, differences of managerial coaching behaviours of mangers in different levels and different organizations. Secondly, correlation analysis was adopted to report correlation coefficient of variables and Cronbach's alphas of measures which were used in this study.

\section{Results}

\subsection{Difference Analysis of Descriptive Characteristics}

Besides the significant higher score of female managers in supporting dimension of managerial coaching behaviours (Male: $M=67.25, S D=13.95$; Female: $M=72.16, S D=12.07, p<0.05$ ), there is no difference in other variables in regard with gender.

According to the single factor analysis of variance (One-way ANOVA), scores of middle and senior managers in challenging and supporting dimensions of managerial coaching behaviours are higher than those of first-line managers and technicians with titles. There is no significant difference between middle and senior managers and first-line managers and technicians with titles in assessing and other variables. The results are presented in Table 1 .

According to the single factor analysis of variance (One-way ANOVA), scores of different organizations in challenging and supporting dimensions of managerial coaching behaviours are different. Managers in hospital and China Mobile and Telecom reported significant higher scores in challenging and supporting than did those 
in factories. There is no significant difference among different organizations in assessing. The results are presented in Table 2.

\subsection{Correlation Analysis}

Correlation coefficients of variables (including age) and Cronbach's alphas of measures used in this study are shown in Table 3. According to correlation analysis, as shown in Table 3, there is a significant positive correlation between age and job satisfaction, life satisfaction, pleasure, challenging and supporting. Job satisfaction is significantly positively related with pleasure, meaning and engagement. Life satisfaction is significantly positively related with meaning, engagement and assessing. Pleasure of life in the Orientations to Happiness Scale is significantly positively associated with assessing and challenging of managerial coaching behaviours.

\section{Discussion}

Managerial coaching behaviours are not associated with job satisfaction and life satisfaction, which is different from previous studies. Hypothesis 1 and 2 was not confirmed. The reason for this can attribute to the fact that the Chinese Managerial Coaching Behaviour Inventory used in this study is different from the scales which were used by other scholars in previous studies. For instance, Alexander et al. (2005) [2] adopted an exploratory

Table 1. Differences of managerial coaching behaviours of managers in different levels.

\begin{tabular}{ccccccc}
\hline \multirow{2}{*}{$\begin{array}{c}\text { Managerial Levels } \\
\text { Dimensions }\end{array}$} & Technicians with Titles & First-Line Managers & $\begin{array}{c}\text { Middle and Senior } \\
\text { Managers }\end{array}$ & F & & p \\
\cline { 2 - 5 } & $\mathrm{M} \pm \mathrm{SD}$ & $\mathrm{M} \pm \mathrm{SD}$ & $\mathrm{M} \pm \mathrm{SD}$ & & & $>0.05$ \\
Assessing & $35.81 \pm 9.14$ & $37.53 \pm 6.11$ & $38.3 \pm 5.07$ & 5.19 & $<0.01$ \\
Challenging & $50.83 \pm 12.4$ & $54.06 \pm 8.33$ & $57.95 \pm 6.58$ & 5.16 & $<0.05$ \\
Supporting & $66.13 \pm 16.71$ & $71.98 \pm 11.87$ & $72.89 \pm 8.2$ & 3.25 & \\
\hline
\end{tabular}

Table 2. Differences of managerial coaching behaviours in different organizations.

\begin{tabular}{|c|c|c|c|c|c|}
\hline \multirow{2}{*}{$\begin{array}{l}\text { Organizations } \\
\text { Dimensions }\end{array}$} & Factories & Hospitals & $\begin{array}{c}\text { China Mobile and } \\
\text { China Telecom }\end{array}$ & \multirow{2}{*}{$\mathrm{F}$} & \multirow{2}{*}{$\mathrm{p}$} \\
\hline & $\mathrm{M} \pm \mathrm{SD}$ & $\mathrm{M} \pm \mathrm{SD}$ & $\mathrm{M} \pm \mathrm{SD}$ & & \\
\hline Assessing & $35.29 \pm 9.11$ & $37.29 \pm 6.54$ & $38.32 \pm 4.96$ & 1.98 & $>0.05$ \\
\hline Challenging & $51.1 \pm 12.9$ & $53.11 \pm 8.55$ & $58.68 \pm 5.01$ & 6.3 & $<0.01$ \\
\hline Supporting & $63.83 \pm 17.79$ & $72.67 \pm 9.72$ & $71.71 \pm 9.7$ & 6.81 & $<0.01$ \\
\hline
\end{tabular}

Table 3. Correlation coefficient and cronbach's $\alpha$.

\begin{tabular}{|c|c|c|c|c|c|c|c|c|c|}
\hline Measures & Age & Job Satisfaction Life & Satisfaction & Pleasure & Meaning & Engagement & Assessing & Challenging & Supporting \\
\hline Job Satisfaction & $0.31^{* * *}$ & 1 & & & & & & & \\
\hline Life Satisfaction & $0.20^{*}$ & $0.72^{* * *}$ & 1 & & & & & & \\
\hline Pleasure & $0.20^{*}$ & $0.30^{* * *}$ & $0.38^{* * *}$ & 0.67 & & & & & \\
\hline Meaning & 0.01 & $0.34^{* * *}$ & $0.38^{* * *}$ & $0.50^{* * *}$ & 0.72 & & & & \\
\hline Engagement & 0.15 & $0.44^{* * *}$ & $0.47^{* * *}$ & $0.59^{* * *}$ & $0.59^{* * *}$ & 0.71 & & & \\
\hline Assessing & 0.14 & -0.04 & 0.02 & $0.22^{*}$ & 0.08 & 0.01 & 0.88 & & \\
\hline Challenging & $0.23^{* *}$ & -0.09 & -0.02 & $0.25^{* *}$ & 0.08 & 0.04 & $0.87^{* * *}$ & 0.93 & \\
\hline Supporting & $0.28^{* *}$ & -0.16 & -0.08 & 0.12 & 0.10 & -0.05 & $0.82^{* * *}$ & $0.85^{* * *}$ & 0.94 \\
\hline
\end{tabular}

Note: ${ }^{*} \mathrm{p}<0.05, \quad{ }^{* *} \mathrm{p}<0.01,{ }^{* * *} \mathrm{p}<0.001$. 
eight-item measure for managerial coaching behaviour on the basis of Ellinger and Bostrom's (1999) [20] behavioural themes.

Hypothesis 3 is partly confirmed. It suggests that assessing and challenging behaviours can lead to pleasure of life such as the aesthetic sense in the process of intellectual stimulation.

Hypothesis 4 is well confirmed. This result indicates that orientations to happiness can be increased with the increase of job satisfaction. Due to the fact that managerial coaching behaviours are not associated with job satisfaction, other variables which can increase job satisfaction are needed to be found in future research in order to find out a feasible way to increase orientations to happiness. Life satisfaction is significantly positively correlated with two dimensions in Orientations to Happiness, which confirmed previous findings (Peterson et al., 2005; Chen, 2010) [11] [49].

Managers in higher level of job positions perform more challenging and supporting behaviours. This result can be explained as follows. Managers in higher positions have higher social status and enjoy higher quality of lives. This result of this study is consistent with previous studies (Oshagbemi, 2003; Verhofstadt et al., 2007; Chen, Huang \& Tang, 2013) [40] [43] [64].

There is a significant positive correlation between age and job satisfaction. It indicates that job satisfaction is higher with the increase of age. The result of this study is consistent with the previous surveys (Chen, 2010) [11]. This study fills the gap of previous studies and made a further step (Chen, Huang, \& Tang, 2013) [64]. It suggests that managers perform more challenging and supporting behaviours with the increase of age. The reasons for the increase of job satisfaction, pleasure of life and challenging and supporting managerial behaviours can be illustrated as follows: with the increase of age, people become more experienced and have more authority in Chinese culture. Therefore, they tend to have more power and work in higher job positions.

\section{Conclusions}

All in all, in this research we found that there is a significant difference between managerial coaching behaviours of managers in factories such as shoe factories and printing factories and those in hospitals, China Mobile and China Telecom. The results indicate that there are fewer challenging and supporting behaviours of managers in factories than those in hospitals, China Mobile and China Telecom. The reasons for this can be as follows. Managers in factories are responsible for operation management which is a routine management with little demand of creativity. They manage people with low-level education. Managers in hospitals, China Mobile and China Telecom are responsible for creative jobs or tasks. They manage people with better education and those people are required to meet more standards in managerial coaching behaviours.

Scores of middle and senior managers in challenging and supporting dimensions are higher than first-line mangers and technical staffs with titles. On One hand, job satisfaction is significantly positively related with three dimensions in Orientations to Happiness. On the other hand Managerial coaching behaviours can not be improved through the increase of job satisfaction and life satisfaction of managers. Also, improvement of managerial coaching behaviours is not helpful to the increase of mangers' job satisfaction and life satisfaction.

Further, there is a significant positive correlation between age and pleasure. It indicates that the increase of age leads to increase of pleasure of life. There is a significant correlation between age and challenging and supporting managerial coaching behaviours. And the Pleasure of life in the Orientations to Happiness Scale is significantly associated with assessing and challenging dimensions of Managerial Coaching Behaviours Inventory.

\section{Limitations and Implications}

There are several limitations of this study. Firstly, the sample size is not large enough. In future research, the size of sample can be enlarged. Also, managerial coaching behaviours in more various industries can be compared in future research. Secondly, there is only one item in General Job Satisfaction Scale and General life Satisfaction Scale, scales with more items can be used to assess job satisfaction and life satisfaction. Finally, this study discusses managerial coaching behaviours and their relations with job satisfaction, life satisfaction and orientations to happiness in Chinese context.

Managerial coaching behaviours and their relations to other variables can be studied in the future in order to find out the most influential factors to managerial coaching behaviours in Chinese context. In future research, the relation between managers' coaching behaviours and their subordinates' job satisfaction can be also studied. 


\section{References}

[1] Jones, R.A., Rafferty, A.E. and Griffin, M.A. (2006) The Executive Coaching Trend: Towards More Flexible Executives. Leadership \& Organization Development Journal, 27, 584-596. http://dx.doi.org/10.1108/01437730610692434

[2] Ennis, S.A., Hodgetts, W.H., Otto, J., Stern, L.R., Vitti, M. and Yahanda, N. (2004) The Executive Coaching Handbook: Principles and Guidelines for a Successful Coaching Partnership. The Executive Coaching Forum, Wellesley.

[3] Richard, P. (1994) Coaching for Higher Performance. Management Development Review, 7, 19-22. http://dx.doi.org/10.1108/09622519410771691

[4] Goodstone, M.S. and Diamante, T. (1998) Organizational Use of Therapeutic Change: Strengthening Multi-Score Feedback Systems through Interdisciplinary Coaching. Consulting Psychology Journal: Practice and Research, 50, 152-163. http://dx.doi.org/10.1037/1061-4087.50.3.152

[5] Hudson, F.M. (1999) The Handbook of Coaching: A Comprehensive Resource Guide for Managers, Consultants, and Human Resource Professionals. Jossey Bass, San Francisco.

[6] Longenecker, C.O. (2010) Coaching for Better Results: Key Practices of High Performance Leaders. Industrial and Commercial Training, 42, 32-40. http://dx.doi.org/10.1108/00197851011013698

[7] Ellinger, A.D. and Bostrom, R.P. (1999) Managerial Coaching Behaviours in Learning Organizations. Journal of Management Development, 18, 752-771. http://dx.doi.org/10.1108/02621719910300810

[8] Beattie, R.S. (2002) Developmental Managers: Line Managers as Facilitators of Workplace Learning in Voluntary Organizations. Unpublished Doctoral Thesis, University of Glasgow, Glasgow.

[9] Talarico, M. (2002) Manager as Coach in a Pharmacy Benefit Management Organization: A Critical Incidents Analysis. Unpublished Doctoral Dissertation. University of Minnesota, Crookston, MN.

[10] Graham, S., Wedman, J. and Garvin-Kester, B. (1993) Manager Coaching Skills: Development and Application. Performance Improvement Quarterly, 6, 2-13. http://dx.doi.org/10.1111/j.1937-8327.1993.tb00569.x

[11] Graham, S., Wedman, J. and Garvin-Kester, B. (1994) Manager Coaching Skills: What Makes a Good Coach? Performance Improvement Quarterly, 7, 81-94. http://dx.doi.org/10.1111/j.1937-8327.1994.tb00626.x

[12] Janka, I.S. (2008) Effects of Team Tenure and Leadership in Self-Managing Teams. Personnel Review, 37, 564-582. http://dx.doi.org/10.1108/00483480810891682

[13] Clinton, O.L. (2010) Coaching for Better Results: Key Practices of High Performance Leaders. Industry and Commercial Training, 42, 32-40. http://dx.doi.org/10.1108/00197851011013698

[14] Andrea, D.E., Robert, G.H. and Rona, S.B. (2008) Behavioural Indicators of Ineffective Managerial Coaching-A Cross-National Study. Journal of European Industrial Training, 32, 240-257. http://dx.doi.org/10.1108/03090590810871360

[15] Alexander, E.E., Andrea, D.E. and Scott, B.K. (2005) Supervisory Coaching in a Logistics Context. International Journal of Physical Distribution \& Logistics Management, 35, 620-636. http://dx.doi.org/10.1108/09600030510634562

[16] Noer, D.M. (2005) Behaviourally Based Coaching: A Cross-Cultural Case Study. International Journal of Coaching in Organizations, 3, 14-23.

[17] Noer, D.M., Christopher, R.L. and Matthew, V. (2007) An Analysis of Saudi Arabian and US Managerial Coaching Behaviors. Journal of Managerial Issues, 19, 271-287.

[18] McCauley, C.D., Moxley, R.S. and VanVelsor, E., Eds. (1998) The Center for Creative Leadership Handbook of Leadership Development. Jossey-Bass, San Francisco.

[19] Argyris, G., Ed. (1973) Intervention Theory and Method. Addison-Wesley, Reading.

[20] Vroom, V.H., Ed. (1964) Work and Motivation. Wiley, New York.

[21] Brayfield, A. and Crockett, W. (1955) Employee Attitudes and Employee Performance. Psychological Bulletin, 52, 396-424. http://dx.doi.org/10.1037/h0045899

[22] Lawler, E. and Porter, L. (1967) The Effects of Performance on Job Satisfaction. Industrial Relations, 7, $20-28$. http://dx.doi.org/10.1111/j.1468-232X.1967.tb01060.x

[23] Schwab, D. and Cummings, L. (1970) Theories of Performance and Satisfaction: A Review. Industrial Relations, 9, 408-430. http://dx.doi.org/10.1111/j.1468-232X.1970.tb00524.x

[24] Organ, D.W. (1977) A Reappraisal and Reinterpretation of the Satisfaction-Causes-Performance Hypothesis. Academy of Management Review, 2, 46-53. http://dx.doi.org/10.2307/257604 http://dx.doi.org/10.5465/AMR.1977.4409162

[25] Petty, M., McGee, G. and Cavender, J. (1984) A Meta-Analysis of the Relationship between Individual Job Satisfac- 
tion and Individual Performance. Academy of Management Review, 9, 712-721. http://dx.doi.org/10.2307/258493 http://dx.doi.org/10.5465/AMR.1984.4277608

[26] Crossman, A. and Nestle, B.A. (2003) Job Satisfaction and Employee Performance of Lebanese Banking Staff. Middle East, Dubai, United Arab Emirates Journal of Managerial Psychology, 18, 368-376. http://dx.doi.org/10.1108/02683940310473118

[27] Gibson, J.L. and Klein, S.M. (1970) Employee Attitudes as a Function of Age and Length of Service: A Reconceptualization. Academy of Management Journal, 13, 411-425. http://dx.doi.org/10.2307/254831

[28] Lee, R. and Wilbur, E. (1985) Age, Education, Job Tenure, Salary, Job Characteristics and Job Satisfaction: A Multivariate Analysis. Human Relations, 38, 781-791. http://dx.doi.org/10.1177/001872678503800806

[29] Kong, B.A., Chye, T.G. and Hian, C.K. (1993) The Impact of Age on the Job Satisfaction of Accountants. Personnel Review, 22, 31-39. http://dx.doi.org/10.1108/00483489310025184

[30] Clark, A.E. (1996) Job Satisfaction in Britain. Journal of Industrial Relations, 32, 189-217. http://dx.doi.org/10.1111/j.1467-8543.1996.tb00648.x

[31] Murray, M.A. and Atkinson, T. (1981) Gender Differences in Correlates of Job Satisfaction. Canadian Journal of Behavioural Sciences, 13, 44-52. http://dx.doi.org/10.1037/h0081119

[32] Witt, L.A. and Nye, L.G. (1992) Gender and the Relationship between Perceived Fairness of Pay or Promotion and Job Satisfaction. Journal of Applied Psychology, 77, 910-917. http://dx.doi.org/10.1037/0021-9010.77.6.910

[33] Chui, C. (1998) Do Professional Women Have Lower Job Satisfaction than Professional Men? Lawyers as a Case Study. Sex Roles: A Journal of Research, 38, 521-538. http://dx.doi.org/10.1023/A:1018722208646

[34] Staw, B. and Ross, J. (1985) Stability in the Midst of Change: A Dispositional Approach to Job Attitudes. Journal of Applied Psychology, 70, 469-480. http://dx.doi.org/10.1037/0021-9010.70.3.469

[35] Arvey, R., Bouchard, T., Segal, N. and Abraham, L. (1989) Job Satisfaction: Environmental and Genetic Components. Journal of Applied Psychology, 74, 187-192. http://dx.doi.org/10.1037/0021-9010.74.2.187

[36] House, R., Shane, S. and Herold, D. (1996) Rumors of the Death of Dispositional Research Are Vastly Exaggerated. Academy of Management Review, 21, 203-224. http://dx.doi.org/10.5465/AMR.1996.9602161570 http://dx.doi.org/10.2307/258634

[37] Abraham, R. (1998) Emotional Dissonance in Organizations: A Conceptualization of Consequences, Mediators and Moderators. Leadership and Organization Development Journal, 19, 137-146. http://dx.doi.org/10.1108/01437739810210185

[38] Pelled, L. and Xin, K. (1999) Down and Out: An Investigation of the Relationship between Mood and Employee Withdrawal Behaviour. Journal of Management, 25, 875-895. http://dx.doi.org/10.1177/014920639902500605

[39] Droussiotis, A. (2007) Job Satisfaction of Managers in Cyprus. Euro Med Journal of Business, 2, $208-222$. http://dx.doi.org/10.1108/14502190710826068

[40] Verhofstadt, E., De Witte, H. and Omey, E. (2007) Higher Educated Workers: Better Jobs but Less Satisfied? International Journal of Manpower, 28, 135-151. http://dx.doi.org/10.1108/01437720710747965

[41] McCausland, W.D., Pouliakas, K. and Theodossiou, I. (2005) Some Are Punished and Some Are Rewarded: A Study of the Impact of Performance Pay on Job Satisfaction. International Journal of Manpower, 26, 636-659. http://dx.doi.org/10.1108/01437720510628112

[42] Kavanaugh, J., Duffy, J.A. and Lilly, J. (2006) The Relationship between Job Satisfaction and Demographic Variables for Healthcare Professionals. Management Research News, 29, 304-325. http://dx.doi.org/10.1108/01409170610683842

[43] Oshagbemi, T. (2003) Personal Correlates of Job Satisfaction: Empirical Evidence from UK Universities. International Journal of Social Economics, 30, 1210-1232. http://dx.doi.org/10.1108/03068290310500634

[44] Hart, P. (1999) Predicting Employee Life Satisfaction: A Coherent Model of Personality, Work and Non-Work Experiences and Domain Satisfactions. Journal of Applied Psychology, 84, 564-584. http://dx.doi.org/10.1037/0021-9010.84.4.564

[45] Judge, T.A., Locke, E.A., Durham, C.C., et al. (1998) Dispositional Effects on Job and Life Satisfaction: The Role of Core Evaluations. Journal of Applied Psychology, 83, 17-34. http://dx.doi.org/10.1037/0021-9010.83.1.17

[46] Diener (2009) Subjective Well-Being. Social Indicators Research, 37. http://dx.doi.org/10.1007/978-90-481-2350-6

[47] Campbell, A., Converse, P.E. and Rodgers, W.L., Eds. (1976) The Quality of American Life. Russell Sage Foundation, New York.

[48] Diener, E., Emmons, R.A., Larsen, R.J. and Griffin, S. (1985) The Satisfaction with Life Scale. Journal of Personality Assessment, 49, 71-75. http://dx.doi.org/10.1207/s15327752jpa4901_13 
[49] Watson, D., Clark, L.A. and Tellegen, A. (1988) Development and Validation of a Brief Measure of Positive and Negative Affect: The PANAS Scales. Journal of Personality and Social Psychology, 54, 1063-1070. http://dx.doi.org/10.1037/0022-3514.54.6.1063

[50] Pavot, W., Diener, E. and Suh, E. (1998) The Temporal Satisfaction with Life Scale. Journal of Personality Assessment, 70, 340-354. http://dx.doi.org/10.1207/s15327752jpa7002 11

[51] Argyle, M., Martin, M. and Lu, L., Eds. (1995) Testing for Stress and Happiness: The Role of Social and Cognitive Factors. In: Spielberger, C.D. and Sarason, I.G., Eds., Stress and Emotion, Taylor \& Francis, Washington DC, 173-187.

[52] Hills, P. and Argyle, M. (1998) Positive Moods Derived from Leisure and Their Relation to Happiness and Personality. Personality and Individual Differences, 25, 523-535. http://dx.doi.org/10.1016/S0191-8869(98)00082-8

[53] Peterson, C., Park, N. and Seligman, M.E.P. (2005) Orientations to Happiness and Life Satisfaction: The Full Life versus the Empty Life. Journal of Happiness Studies, 6, 25-41. http://dx.doi.org/10.1007/s10902-004-1278-z

[54] Veenhoven, R. (1994) Is Happiness a Trait? Social Indicators Research, 32, 101-160. http://dx.doi.org/10.1007/BF01078732

[55] Chen, G.H. (2010) Validating the Orientations to Happiness Scale in a Chinese Sample of University Students. Social Indicators Research, 99, 431-442. http://dx.doi.org/10.1007/s11205-010-9590-y

[56] Ruch, W., Huber, A., Beermann, U. and PrÖyer, R.T. (2007) Character Strengths as Predictors of the "Good Life" in Austria, Germany and Switzerland. Social Sciences, 16, 123-131.

[57] Park, N., Peterson, C. and Ruch, W. (2009) Orientations to Happiness and Life Satisfaction in Twenty-Seven Nations. The Journal of Positive Psychology, 4, 273-279. http://dx.doi.org/10.1080/17439760902933690

[58] Watkins, R. and Leigh, D., Eds. (2010) Handbook of Improving Performance in the Workplace, the Handbook of Selecting and Implementing Performance Interventions (Volume 2). International Society for Performance Improvement, California.

[59] Millard, L. (1996) Differences in Coaching Behaviours of Male and Female High School Soccer Coaches. Journal of Sport Behaviour, 19, 19-31.

[60] Smith, R.E., Smoll, F.L. and Curtis, B. (1979) Coach Effectiveness Training: A Cognitive-Behavioural Approach to Enhancing Relationship Skills in Youth Sport Coaches. Journal of Sport Psychology, 1, 59-75.

[61] Black, S.J. and Weiss, M.R. (1992) The Relationship among Perceived Coaching Behaviours, Perceptions of Ability and Motivation in Competitive Age-Group Swimmers. Journal of Sport and Exercise Psychology, 14, 309-325.

[62] Sussman, L. and Finnegan, R. (1998).Coaching the Star: Rationale and Strategies. Business Horizons, 41, 47-54. http://dx.doi.org/10.1016/S0007-6813(98)90034-9

[63] Ellinger, A.D., Ellinger, A.E. and Keller, S.B. (2003) Supervisory Coaching Behaviour, Employee Satisfaction and Warehouse Employee Performace: A Dyadic Perspective in the Distribution Industry. Human Resource Development Quarterly, 14, 435-458. http://dx.doi.org/10.1002/hrdq.1078

[64] Chen, G., Huang, W. and Tang, Y. (2013) Predicting Managerial Coaching Behaviors by the Big-Five Personality Traits[J]. Journal of Human Resource and Sustainability Studies, 1, 76-84. http://dx.doi.org/10.4236/jhrss.2013.14011 
Scientific Research Publishing (SCIRP) is one of the largest Open Access journal publishers. It is currently publishing more than 200 open access, online, peer-reviewed journals covering a wide range of academic disciplines. SCIRP serves the worldwide academic communities and contributes to the progress and application of science with its publication.

Other selected journals from SCIRP are listed as below. Submit your manuscript to us via either submit@scirp.org or Online Submission Portal.
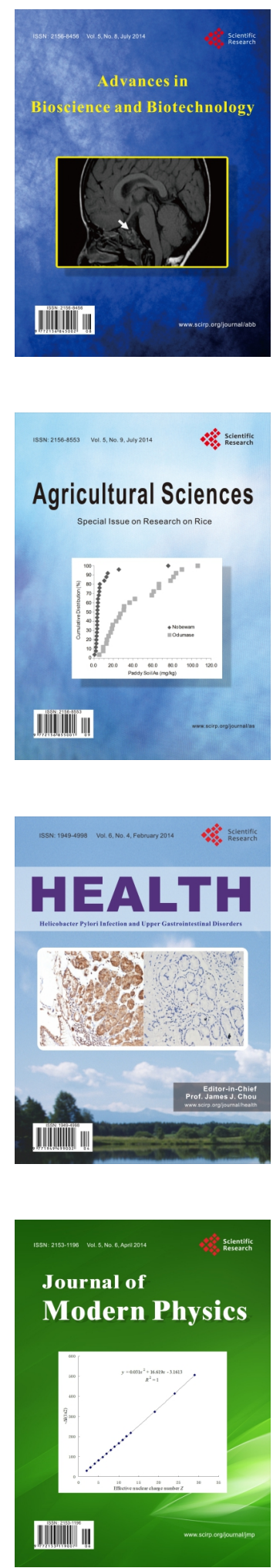
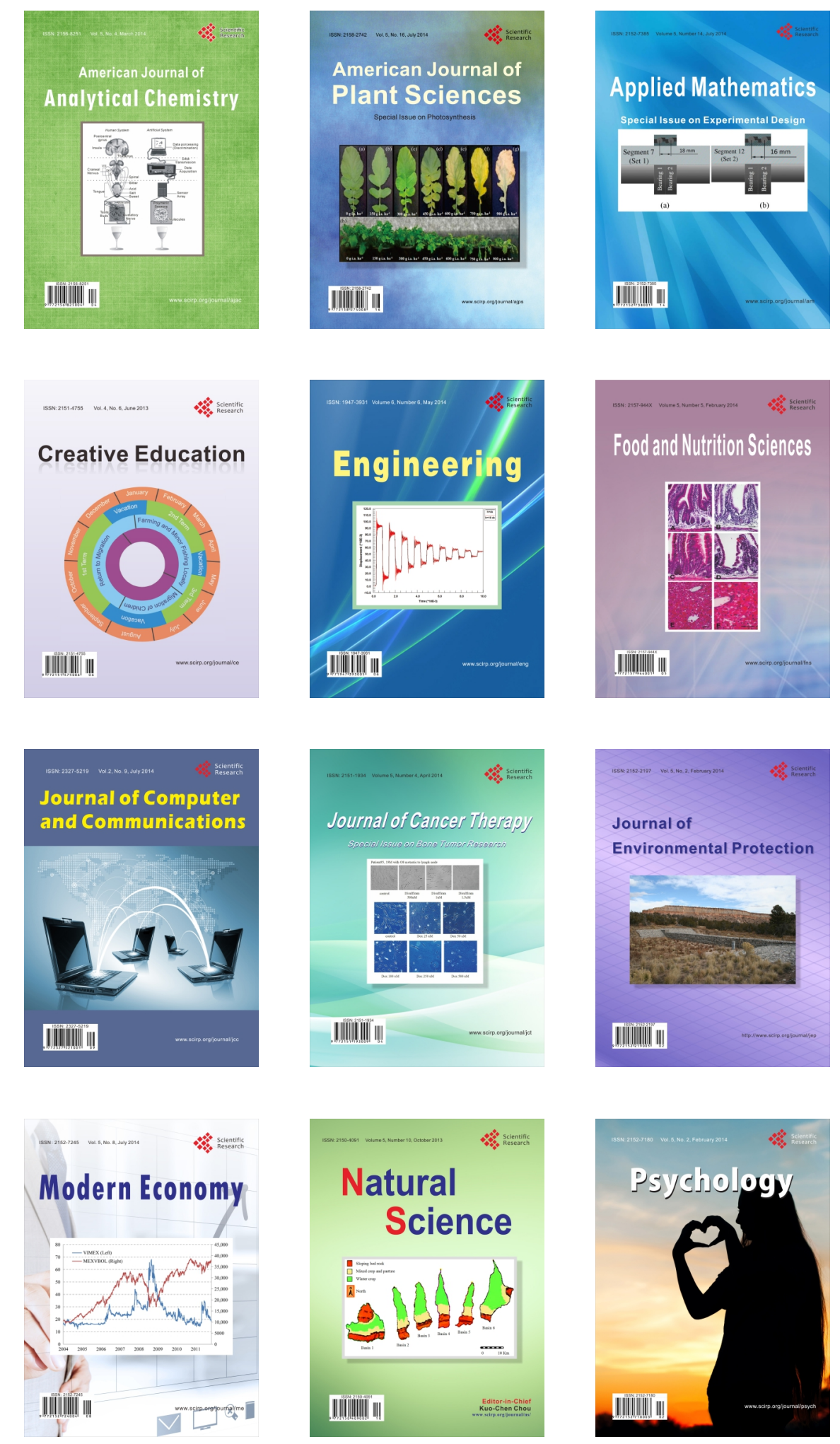